\title{
Lack of association of genetic variation in chromosome region I 5q I 4-22. I with type 2 diabetes in a Japanese population
} Yuka Yamaguchi ${ }^{1}$, Maki Moritani ${ }^{1}$, Toshihito Tanahashi ${ }^{1}$, Dai Osabe ${ }^{2}$, Kyoko Nomura², Yuka Fujita1, Parvaneh Keshavarz' ${ }^{1}$, Kiyoshi Kunika1, Naoto Nakamura ${ }^{3}$, Toshikazu Yoshikawa ${ }^{3}$, Eiichiro Ichiishi ${ }^{4}$, Hiroshi Shiota ${ }^{5}$, Natsuo Yasui ${ }^{6}$, Hiroshi Inoue ${ }^{1}$ and Mitsuo Itakura*1

Address: ${ }^{1}$ Division of Genetic Information, Institute for Genome Research, The University of Tokushima, 3-18-15, Kuramoto-cho, Tokushima, 770-8503, Japan, ${ }^{2}$ Department of Bioinformatics, Division of Life Science Systems, Fujitsu Limited, 1-5-2, Higashishinbashi, Minato-ku, Tokyo, 105-7123, Japan, ${ }^{3}$ Department of Endocrinology and Metabolism, Kyoto Prefectural University of Medicine Graduate School of Medical Science, 465, Kajii-cho, Hirokoji-Kawaramachi, Kamigyo-ku, Kyoto, 602-8566, Japan, ${ }^{4}$ New Industry Creation Hatchery Center, Tohoku University, Aramaki, Aoba-ku, Sendai, Miyagi, 980-8579, Japan, ${ }^{5}$ Department of Ophthalmology and Visual Neuroscience, Institute of Health Bioscience, The University of Tokushima, 770-8503, Japan and ' ${ }^{2}$ epartment of Orthopedics, Institute of Health Biosciences, The University of Tokushima, 770 8503, Japan

Email: Yuka Yamaguchi - yama@genome.tokushima-u.ac.jp; Maki Moritani - moritani@genome.tokushima-u.ac.jp;

Toshihito Tanahashi - tana@genome.tokushima-u.ac.jp; Dai Osabe -d_osabe@jp.fujitsu.com; Kyoko Nomura - nomura.kyoko@jp.fujitsu.com; Yuka Fujita - fujita@genome.tokushima-u.ac.jp; Parvaneh Keshavarz - parvaneh@genome.tokushima-u.ac.jp;

Kiyoshi Kunika - kunika@genome.tokushima-u.ac.jp; Naoto Nakamura - naoto@koto.kpu-m.ac.jp; Toshikazu Yoshikawa - toshi@koto.kpum.ac.jp; Eiichiro Ichiishi - ichiishi@XG7.SO-NET.ne.jp; Hiroshi Shiota - shiota@clin.med.tokushima-u.ac.jp;

Natsuo Yasui - nyasui@clin.med.tokushima-u.ac.jp; Hiroshi Inoue - hinoue@genome.tokushima-u.ac.jp;

Mitsuo Itakura* - itakura@genome.tokushima-u.ac.jp

* Corresponding author

Published: 27 March 2008

BMC Medical Genetics 2008, 9:22 doi:10.1 186/147I-2350-9-22
Received: 31 July 2007

Accepted: 27 March 2008

This article is available from: http://www.biomedcentral.com/I47/-2350/9/22

(C) 2008 Yamaguchi et al; licensee BioMed Central Ltd.

This is an Open Access article distributed under the terms of the Creative Commons Attribution License (http://creativecommons.org/licenses/by/2.0), which permits unrestricted use, distribution, and reproduction in any medium, provided the original work is properly cited.

\begin{abstract}
Background: Chromosome 15q I4-22.I has been linked to type 2 diabetes (T2D) and its related traits in Japanese and other populations. The presence of T2D disease susceptibility variant(s) was assessed in the $21.8 \mathrm{Mb}$ region between $D / 5 S / / 8$ and D/5SII 7 in a Japanese population using a region-wide case-control association test.

Methods: A two-stage association test was performed using Japanese subjects: The discovery panel (Stage I) used 372 cases and 360 controls, while an independent replication panel (Stage 2) used 532 cases and 530 controls. A total of I,3I7 evenly-spaced, common SNP markers with minor allele frequencies $>0.10$ were typed for each stage. Captured genetic variation was examined in HapMap JPT SNPs, and a haplotype-based association test was performed.
\end{abstract}

Results: SNP2 I 40 ( $r$ 24I 2747) (C/T) in intron 33 of the ubiquitin protein ligase E3 component n-recognin I (UBRI) gene was selected as a landmark SNP based on repeated significant associations in Stage I and Stage 2. However, the marginal $p$ value $(p=0.0043$ in the allelic test, $O R=1.26,95 \% \mathrm{Cl}=1.07-1.48$ for combined samples) was weak in a single locus or haplotype-based association test. We failed to find any significant SNPs after correcting for multiple testing.

Conclusion: The two-stage association test did not reveal a strong association between $\mathrm{T} 2 \mathrm{D}$ and any common variants on chromosome 15q14-22.I in I,794 Japanese subjects. A further association test with a larger sample size and denser SNP markers is required to confirm these observations. 


\section{Background}

Insulin resistance in muscle, adipose, and liver tissues and impaired insulin secretion from pancreatic $\beta$ cells contribute to the pathogenesis of type 2 diabetes (T2D) [1]. Analyses using a traditional candidate gene approach and, more recently, genome-wide association studies (GWAS) [2-7], have generated a large amount of data that have confirmed 11 genes with replicated association with T2D in Caucasians [8]. However, the assessment in Japanese T2D patients, who characteristically have a lower body mass index (BMI) and a lower fasting insulin level than Caucasians [9], has not been largely performed. These differences suggest that Japanese individuals with T2D might have a different genetic background from other populations, and susceptibility variant(s) or gene(s) for the development of T2D in Japanese can only be identified with genetic assessment. Because candidate regions supported by replicated linkage signals in Japanese and other populations are expected to map T2D susceptibility gene(s), a region-wide association test was used as an alternative affective approach with the availability of unbiased reliability, timeliness and cost efficiency.

Among a number of proposed candidate regions for T2D and its related traits [10], the chromosome 15q14-22.1 candidate region is supported by replicated linkage signals of non-overlapping samples from Japanese subjects. In three studies of genome-wide linkage scan of Japanese subjects [11-13], chromosome 15q14-22.1 showed significant evidence of linkage with T2D (LOD = 2.41) [12] and a maximum LOD score (MLS) of 3.91 for early onset T2D [11] (Table 1). This region overlaps candidate region found in other populations, including Mexican Americans
[14] and Pima Indians [15], findings that were replicated in a subsequent study of Mexican Americans [16] (Table $1)$. This candidate region supported by replicated linkage signals is expected to contain susceptibility gene(s). In the absence of convincing comprehensive association data on chromosome $15 \mathrm{q}$, the challenge remains to identify the disease susceptibility variant(s) or gene(s) that definitively contribute to T2D. We focused on chromosome $15 q 14-22.1$ at $32.6-51.2 \mathrm{cM}$ as the susceptibility region in Japanese.

In this study, a region-wide two-stage association test was used to perform a comprehensive examination of genetic variant(s), using 1,317 common SNPs, in a Japanese population comprised of 1,794 unrelated cases and controls.

\section{Methods \\ Subjects}

This study utilized samples obtained from a total of 1,794 Japanese subjects: 904 T2D cases and 890 controls. The majority of T2D patients was recruited from the outpatient clinic of Tokushima University Hospital, Kyoto Prefectural University Hospital and their affiliated hospitals. All T2D diagnoses were based on the 1985 World Health Organization criteria, and patients were clinically defined as having gradual adult onset of the disease with medication. Patients with clinical criteria for monogenic forms of diabetes were excluded. The clinical characteristics of these samples are presented in Table 2. The controls were recruited from healthy adult members of the general population, who were intensively checked for a negative family history of diabetes, normal $\mathrm{HbA}_{1 \mathrm{c}}$ levels of $<5.8 \%$, the absence of other diseases, and Japanese ancestry based on

Table I: Summary of linkage scan on chromosome I5q I4-22.I

\begin{tabular}{|c|c|c|c|c|c|c|}
\hline Population & Sample & Score & Phenotype & STS marker & Position (cM) & References (year) \\
\hline \multirow[t]{5}{*}{ Japanese } & $\begin{array}{l}224 \text { ASP in } 159 \text { families, } 359 \\
\text { individuals }\end{array}$ & $1.57 \mathrm{MLS}$ & $\mathrm{T} 2 \mathrm{D}$ & $D / 55994$ & 40.25 & Mori Y et al. 2002 [ I I] \\
\hline & & 3.91 MLS & T2D (Young-onset < 45) & D/5S994 & 40.25 & \\
\hline & & $2.44 \mathrm{MLS}$ & $\mathrm{T} 2 \mathrm{D}(\mathrm{BMI}<30)$ & D/5S994 & 40.25 & \\
\hline & & $1.50 \mathrm{MLS}$ & $\mathrm{T} 2 \mathrm{D}$ & $D / 5 S I / 8$ & 32.58 & \\
\hline & & $0.95 \mathrm{MLS}$ & $\mathrm{T} 2 \mathrm{D}$ & $D / 5 S I / 7$ & 51.21 & \\
\hline Japanese & $\begin{array}{l}256 \text { ASP in } 164 \text { families, } 368 \\
\text { individuals }\end{array}$ & $2.4 \mathrm{I}$ LOD & T2D $(\mathrm{BMI}<22)$ & CYPI9 & 45.62 & Iwasaki $\mathrm{N}$ et al. 2003 [12] \\
\hline Japanese & 102 ASP in 102 families & 0.25 LOD & $\mathrm{T} 2 \mathrm{D}$ & $D / 5 S 117$ & 51.21 & Nawata $\mathrm{H}$ et al. 2004 [13] \\
\hline Mexican Americans & $\begin{array}{l}330 \text { ASP in } 170 \text { families, } 408 \\
\text { individuals }\end{array}$ & $1.50 \mathrm{MLS}$ & $\mathrm{T} 2 \mathrm{D}$ & $D / 5 S 119$ & 45.62 & Hanis CL et al. 1996 [14] \\
\hline Pima Indians & $\begin{array}{l}388 \text { ASP in } 109 \text { families, } 363 \\
\text { individuals }\end{array}$ & I.46 LOD & $\begin{array}{l}\text { insulin secretion (IVGTT } \\
10)\end{array}$ & $D / 5 S 659$ & 43.47 & Pratley RE et al. 1998 [15] \\
\hline \multirow[t]{2}{*}{ Mexican Americans } & $\begin{array}{l}330 \text { ASP in } 170 \text { families and } \\
363 \text { nondiabetic individuals }\end{array}$ & 1.27 LOD & $\mathrm{T} 2 \mathrm{D}$ & $D / 5 S 119$ & 45.62 & Cox NJ et al. 1999 [16] \\
\hline & $\begin{array}{l}\text { interaction with DI5SII9 } \\
\text { and CYPI9 }\end{array}$ & 4.00 LOD & $\mathrm{T} 2 \mathrm{D}$ & DI5SII9+ CYPI9 & & \\
\hline
\end{tabular}

ASP, affected sib-pairs; MLS, maximum lod score; LOD, logarithm of odds; IVGTT I0, plasma insulin response at I0 min above the basal level during the intravenous glucose tolerance test; DI5SII9 + CYPI9, DI5SII9 interaction with CYPI9 (NIDDMI). Each report identified nominal evidence of linkage or significant evidence of linkage with LOD > 3.9I. Location is shown only for loci with positive evidence of linkage on chromosome I5q. The position is based on the Marshfield recombination genetic map .

http://research.marshfieldclinic.org/genetics/Home/index.asp 
their birthplace information. The controls were primarily recruited from the Pharma SNP Consortium (nation-wide collection of Japanese control subjects) [17] and obtained through the Health Science Research Resources Bank of the Japanese Collection of Research/Japan Health Science Foundation. The subjects were placed in one of two independent panels: the discovery panel (Stage 1; 372 cases and 360 controls) and the replication panel (Stage 2; 532 cases and 530 controls).

Genomic DNA was prepared from peripheral blood leukocytes or EB-virus-immortalized B lymphoblasts using a standard protocol. The study was approved by the Ethical
Committee for Human Genome and Gene Research at the University of Tokushima in accordance with the tenets of the Declaration of Helsinki. Informed consent was obtained from all subjects prior to blood sampling, and all personal information and samples were anonymously analyzed for genotyping.

\section{Association testing of SNP markers and genotyping}

At the onset of this study, there was no sufficient SNPs database, such as HapMap. Thus, we constructed a database of common Japanese SNPs based on the genotyping results of 45 unrelated Japanese control subjects (23 males and 22 females) in a whole genome in collabora-

Table 2: Characteristics of the 1,794 Japanese subjects used in the association tests

\begin{tabular}{|c|c|c|}
\hline Stage I samples (discovery panel) & Cases $(n=372)$ & Controls $(n=360)$ \\
\hline Gender (M/F) & $188 / 184$ & $148 / 2 \mid 2$ \\
\hline Age & $64.4 \pm 10.3$ & $46.3 \pm 19.9$ \\
\hline $\mathrm{HbA}_{\mathrm{IC}}(\%)$ & $7.39 \pm 1.48$ & $4.79 \pm 0.36$ \\
\hline $\mathrm{BMI}\left(\mathrm{kg} / \mathrm{m}^{2}\right)$ & $23.7 \pm 3.5$ & $22.0 \pm 2.9$ \\
\hline Age at onset < $50(\%)$ & $175(47.0)$ & - \\
\hline$\geq 50(\%)$ & $195(52.5)$ & - \\
\hline unknown (\%) & $2(0.5)$ & - \\
\hline Family history (\%) & $125(33.6)$ & - \\
\hline Diabetes in both parents & 11 & \\
\hline Diabetes in one parent & 110 & \\
\hline Diabetes in son or daughter & 4 & \\
\hline Insulin therapy $(+)(\%)$ & $112(30.1)$ & - \\
\hline Stage 2 samples (replication panel) & Cases $(n=532)$ & Controls $(n=530)$ \\
\hline Gender (M/F) & $246 / 286$ & $284 / 246$ \\
\hline Age & $62.0 \pm 10.7$ & $37.8 \pm 11.3$ \\
\hline $\mathrm{HbA}_{I C}(\%)$ & $7.47 \pm 1.43$ & $4.88 \pm 0.33$ \\
\hline BMI $\left(\mathrm{kg} / \mathrm{m}^{2}\right)$ & $23.6 \pm 3.3$ & $22.4 \pm 3.0$ \\
\hline Age at onset $<50(\%)$ & $244(45.9)$ & - \\
\hline$\geq 50(\%)$ & $287(53.9)$ & - \\
\hline unknown (\%) & $\mathrm{I}(0.2)$ & - \\
\hline Family history (\%) & $207(38.9)$ & - \\
\hline Diabetes in both parents & 22 & \\
\hline Diabetes in one parent & 180 & \\
\hline Diabetes in son or daughter & 5 & \\
\hline Insulin therapy $(+)(\%)$ & $172(32.3)$ & - \\
\hline Stage I + Stage 2 combined samples & Cases $(n=904)$ & Controls $(n=890)$ \\
\hline Gender (M/F) & $434 / 470$ & $432 / 458$ \\
\hline Age & $63.0 \pm 10.6$ & $41.2 \pm 15.9$ \\
\hline $\mathrm{HbA}_{\mathrm{IC}}(\%)$ & $7.43 \pm 1.45$ & $4.84 \pm 0.34$ \\
\hline BMI $\left(\mathrm{kg} / \mathrm{m}^{2}\right)$ & $23.6 \pm 3.4$ & $22.3 \pm 3.0$ \\
\hline Age at onset $<50(\%)$ & $419(46.4)$ & - \\
\hline$\geq 50(\%)$ & $482(53.3)$ & - \\
\hline unknown (\%) & $3(0.3)$ & - \\
\hline Family history (\%) & $332(36.7)$ & - \\
\hline Diabetes in both parents & 33 & \\
\hline Diabetes in one parent & 290 & \\
\hline Diabetes in son or daughter & 9 & \\
\hline Insulin therapy $(+)(\%)$ & $284(31.4)$ & - \\
\hline
\end{tabular}


tion with Applied Biosystems (ABI) [18]. Out of 70,099 common (MAF > 0.15) gene-centric and intergenic SNPs made available by this project, we provisionally selected 1,450 evenly-spaced SNPs on chromosome $15 q$ between two sequence-tagged site (STS) markers of D15S118 and D15S117.

The initial selection was based on the following criteria: 1) optimal suitability for the design of TaqMan highthroughput genotyping assays; 2) dense and evenlyspaced SNP coverage in both coding and intergenic regions; 3 ) definition of the gene location in a region between $10 \mathrm{~kb}$ upstream of the transcription start site and $10 \mathrm{~kb}$ downstream of the final exon; 4) a distance $<10 \mathrm{~kb}$ between adjacent SNPs; and 5) common SNPs with a MAF $>0.10$. The criterion of a MAF $>0.10$ was imposed subsequent to the selection of SNPs with a MAF $>0.15$.

SNPs were assayed using TaqMan Universal PCR MasterMix (no UNG; ABI) as previously described [19-21]. The genotyping results were obtained in an auto-call mode, after which two researchers independently assessed the genotyping data. When the ratio of undetermined results to the total samples was greater than $2 \%$ (8/384 including four negative controls) or negative controls without DNA template were incorrectly detected, the genotyping was repeated. Genotyping results were compared to those obtained by direct sequencing as previously described [20] with perfect agreement between the two methods.

\section{Two-stage design of the association test}

We performed a two-stage association test on 1,794 samples by randomly assigning them to two independent panels. In the first test, all of the SNPs were genotyped in Stage 1. Those exhibiting significant allelic or genotypic association $(p<0.05)$ were further examined in Stage 2. In each stage, the association was evaluated with two types of $\chi^{2}$ test (allelic or genotypic) by $2 \times 2$ and $2 \times 3$ contingency tables for the status of cases or controls. Finally, the association was evaluated using the combined samples from both Stages.

The power of this case-control test was calculated based on MAF, a type 1 error rate (false-positive rate), and sample size with the PS program $[22,23]$. The standard Bonferroni's correction was used to evaluate the false-positive rate [24]. In addition, we used the false discovery rate (FDR) approach [25] as implemented with the FDR control program in the $\mathrm{R}$ language [26]. A logistic regression analysis to adjust for age, gender, and BMI was carried out using the SPSS program (ver.12, SPSS Japan Inc., Tokyo, Japan).

\section{Searching for novel SNPs and mutational screening of the UBRI gene}

The 47 coding exons, relevant intron-exon boundaries, and 5 ' and 3 ' UTR of UBR1 gene were screened for putative novel Japanese variants by direct sequencing the genomic DNA of 48 individuals (24 cases and 24 controls). All PCR products were treated with ExoSAP-IT (GE Healthcare, NJ, USA) and sequenced using BigDye Terminator Cycle Sequencing Kit, ver1.1 (ABI) in both directions on a $3730 x l$ automated sequencer (ABI) according to the manufacturer's standard protocol.

\section{Estimation of linkage disequilibrium (LD) analysis for haplotype inference}

Pairwise LD coefficients of $\left|D^{\prime}\right|$ and $r^{2}$ were assessed in Stage 1 samples with SNPAlyze ver 5.1 Pro software (DYNACOM, Japan) [27]. This analysis was performed under the assumption of Hardy-Weinberg equilibrium. Haplotype frequencies for multiple loci were estimated by the maximum-likelihood method with an expectationmaximization (EM) algorithm. Permutation $p$ values were calculated by comparing haplotype frequencies between cases and controls on the basis of 10,000 replications. Haplotype-tagging SNPs (htSNPs) were determined with SNPAlyze ver 5.1 Pro.

\section{The amount of captured genetic variation based on HapMap JPT SNPs}

HapMap JPT SNPs corresponding to $21.8 \mathrm{Mb}$ were investigated [28]. Information on 29,728 SNPs within the target region was downloaded from the HapMap website (release 22) [29]. The density of the 1,317 SNPs (the finally selected SNPs from the 1,450 pre-HapMap SNPs) per 300-kb bin was compared against those in the HapMap JPT SNPs. In addition, we estimated the captured tag SNPs as proxies at $\mathrm{r}^{2}>0.7,0.8$, or 0.9 using Tagger program [30].

\section{Results}

\section{Information of selected SNPs}

One STS marker (D15S118) was located 3.9 Mb proximal to D15S994, which exhibited the highest evidence for linkage in the Japanese subjects with a LOD $=3.91$. The second STS marker (D15S117) located $9.0 \mathrm{Mb}$ distal to D15S119, was linked to T2D susceptibility in Mexican Americans with a LOD $=4.0$ (Table 1 ). Therefore, a 21.8 $\mathrm{Mb}$ interval between D15S118 (32.6 cM, mp; $34.5 \mathrm{Mb}$ ) and D15S117 (51.2 cM, mp; $56.3 \mathrm{Mb})$ was chosen as the target region.

Out of 1,450 SNPs, quality control resulted in the exclusion of 39 SNPs that exhibited ambiguous genotyping qualities. After genotyping the remaining 1,411 SNPs, another 94 with a HWE $p<0.05$ or a low MAF of $<0.10$, an indication of insufficient power to detect statistical sig- 
nificance, were excluded. In the final selection of 1,317 SNPs, 974 were mapped within 152 genes $(65.8 \%$ of the 231 genes based on the NCBI Build 36.1 [31] human genome assembly), and 343 were located in intergenic regions. The average MAF of the 1,317 SNPs was $0.32 \pm$ 0.11 in Stage 1 samples, and the average spacing of the gene-centric SNPs was 9,169 bp per pair of SNPs across the $21.8 \mathrm{Mb}$.

\section{Captured genetic variation relative to HapMap JPT SNPs in the target region}

Coverage of the 1,317 SNPs was more limited than that with 29,728 SNPs of HapMap JPT in the $21.8 \mathrm{Mb}$ region: 1,022 SNPs (78\%) of the 1,317 SNPs were present, while only 295 SNPs (22\%) were not present in the 29,728 HapMap JPT (Figure 1), although they were registered in the public database [32] without information on allele fre- quency in the Japanese population. Figure 1 shows only one gap in 43.6-43.9 $\mathrm{Mb}$ in this study, and the presence of a rare density of SNPs $(<10)$ was observed, particularly in the intergenic region and between $42.1-44.8 \mathrm{Mb}$.

This approach is more efficient if tag SNPs based on the HapMap JPT $r^{2}$ structure are used to find the susceptibility variant [28]. We estimated the captured tag SNPs as proxies, meaning that the SNP showed a strong correlation with one or more SNPs at $\mathrm{r}^{2}>0.7,0.8$, or 0.9 . The density of most tag SNPs was < 10 SNPs per $300-\mathrm{kb}$ bin (Figure 1). Taken together, the coverage of common SNPs variation by our chosen SNP set was rather balanced in both genecentric and intergenic regions, and the average number of common tag SNPs in this study was $30 \%$ of those in the HapMap JPT $\left(\mathrm{r}^{2}>0.8\right)$.

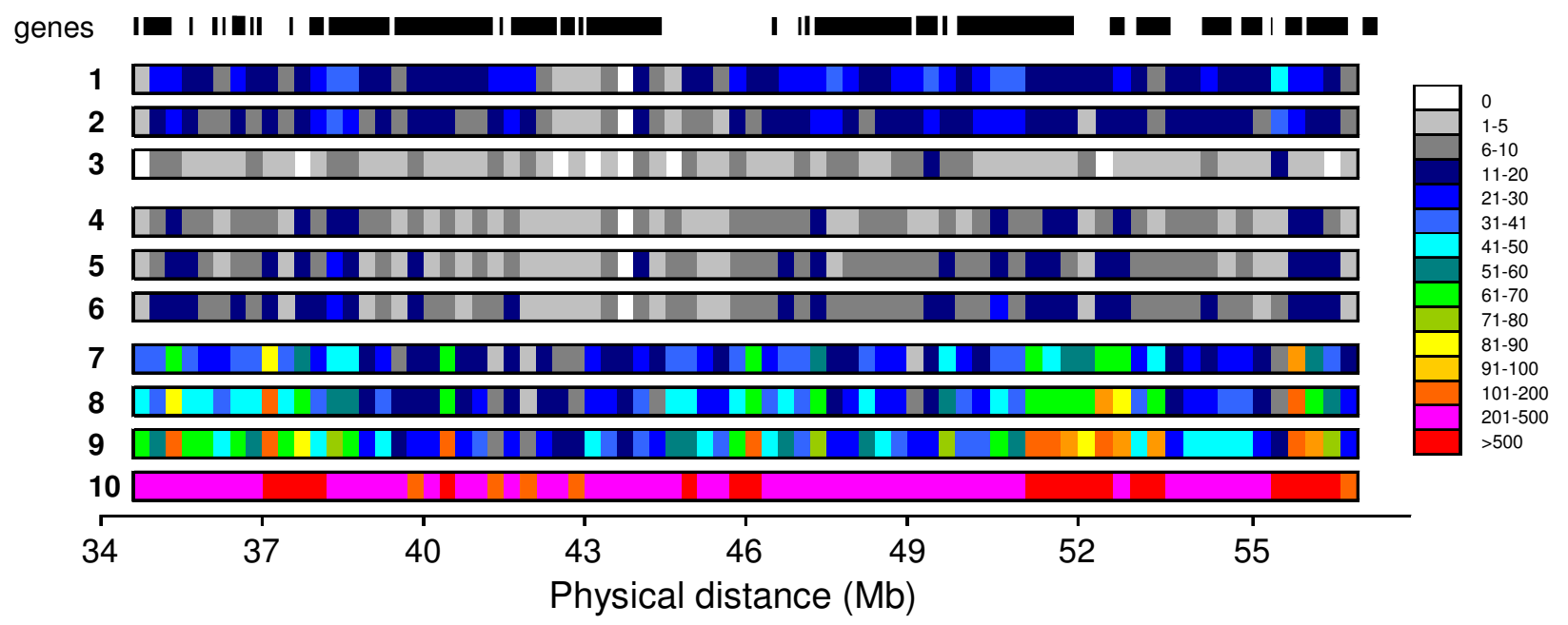

\begin{tabular}{|ll|}
\hline $\mathbf{1}$ & $\mathbf{1 , 3 1 7}$ SNPs \\
$\mathbf{2}$ & 1,022 identical SNPs in HapMap JPT \\
$\mathbf{3}$ & $\mathbf{2 9 5}$ non-identical SNPs in HapMap JPT \\
$\mathbf{4}$ & tag SNPs $\left(\mathrm{r}^{2}>0.7\right)$ found for this study matched with HapMap JPT \\
$\mathbf{5}$ & tag SNPs $\left(\mathrm{r}^{2}>0.8\right)$ found for this study matched with HapMap JPT \\
$\mathbf{6}$ & tag SNPs $\left(\mathrm{r}^{2}>0.9\right)$ found for this study matched with HapMap JPT \\
$\mathbf{7}$ & 2,317 tag SNPs $\left(\mathrm{r}^{2}>0.7\right)$ in HapMap JPT \\
$\mathbf{8}$ & 2,923 tag SNPs $\left(\mathrm{r}^{2}>0.8\right)$ in HapMap JPT \\
$\mathbf{9}$ & 3,968 tag SNPs $\left(\mathrm{r}^{2}>0.9\right)$ in HapMap JPT \\
$\mathbf{1 0}$ & 29,728 SNPs in HapMap JPT \\
\hline
\end{tabular}

Figure I

SNP marker distribution in the target region. Distribution of $I, 317$ SNPs selected for this study (I), I,022 identical (2), and 295 non-identical (3) SNPs in the HapMap JPT database, and distribution of 29,728 SNPs in HapMap JPT (I0) in every 300$\mathrm{kb}$ bin against the physical distance in the target region. Number of tag SNPs $\left(r^{2}>0.7,0.8\right.$, and 0.9$)$ found for this study matched with the $r^{2}>0.7,0.8$, and 0.9 SNPs in HapMap JPT $(4,5$, and 6$)$ and number of tag SNPs $\left(r^{2}>0.7,0.8\right.$, and 0.9$)$ among the HapMap JPT SNPs (7, 8, and 9). The vertical bars in the top panel show the position of RefSeq genes in this region. 


\section{Selection of a landmark SNP}

In Stage 1 association test, 112 SNPs out of 1,317 (8.5\%) showed significant associations $\left(\chi^{2}\right.$ test, $\left.p<0.05\right)$ in the allelic (Figure 2A) or genotypic test. In Stage 2, 11 SNPs out of 112 yielded significant associations $(p<0.05)$ in the allelic (Figure 2B) or genotypic test. However, only one SNP, namely SNP2140 (rs2412747), showed a replicated association for the allelic test $(p<0.05)$ in both stages (Figure 2C). These results suggest that our association test is underpowered. None of the other SNPs showed replicated association for genotypic frequency (Additional file 1).
When the raw data from Stage 1 and Stage 2 were combined, SNP2140 in intron 33 of the ubiquitin protein ligase E3 component n-recognin 1 (UBR1) gene exhibited the nominal significant association with T2D in both the allelic $(p=0.0043$, OR $=1.26,95 \% \mathrm{CI}=1.07-1.48)$ (Figure $2 \mathrm{C}$ ) and genotypic ( $p=0.0081)$ tests. However, a logistic regression analysis revealed that the association between SNP2140 and T2D was not statistically significant after adjustment for age, gender, and BMI. In addition, when the standard Bonferroni's correction for multiple testing was applied (corrected for 1,317 SNPs in the allelic and genotypic tests), the association with SNP2140 was no longer significant. Moreover, FDR for

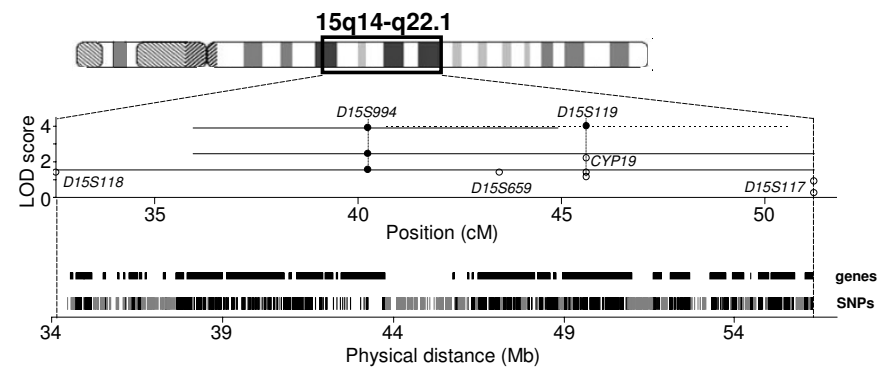

(A) Stage 1

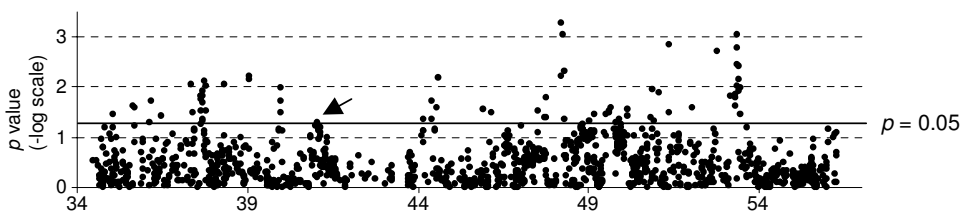

(B) Stage 2

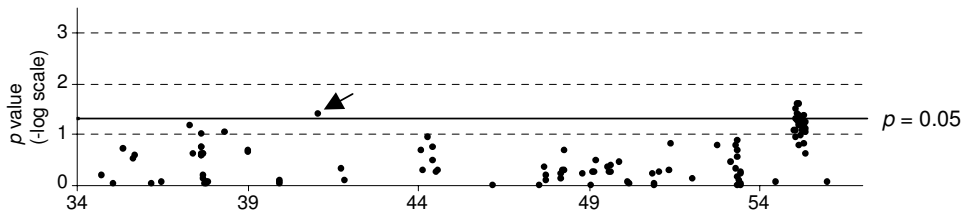

(C) Stage $1+2$ combined

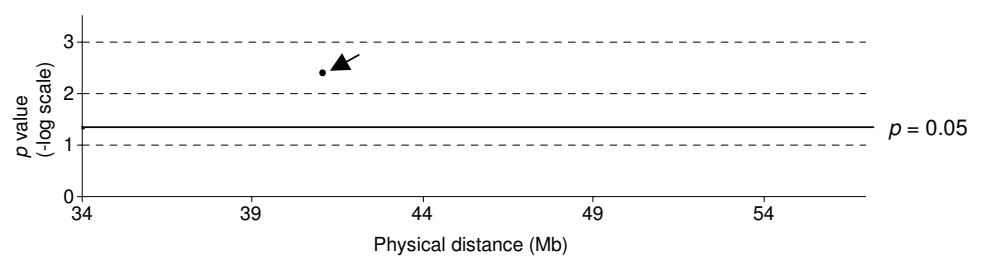

\section{Figure 2}

Association tests on chromosome I5q 14-22. I. Allelic $p$ values in association tests are shown. The top window shows reports of linkage with T2D or its related traits on chromosome I5ql4-22.I in the Japanese and other ethnic populations. The solid and open circles denote LOD scores and location in recombination distance. The width of the straight lines or a broken line denote a I-LOD drop interval when available. The vertical bars show the positions of RefSeq genes (upper) and the I,3 I 7 chosen SNPs (lower) with black vertical bars placed in gene-centric regions and gray vertical bars in intergenic regions. Allelic $p$ values in Stage I (372 cases and 360 controls) for I,3 I 7 SNPs (A), in Stage 2 (532 cases and 530 controls) for I I 2 SNPs (B), and in Stage I + Stage 2 combined samples ( 904 cases and 890 controls) for one replicated SNP (C) were plotted against physical positions. The data denote the $-\log p$, and $p=0.05$ is shown with a thick line. The landmark SNP2 I40 (rs24I2747) is indicated with an arrow. 
112 SNPs in the Stage 2 association test was not significant at a threshold value of 0.1 [25].

The results of association for the top 20 Stage 1-associations using the Armitage trend test are shown in Table 3. Based on the combined $p$ values, three SNPs (SNP3347: rs1386166, SNP3096: rs156787, and SNP2072: rs936216) showed a smaller $p$ value than the landmark SNP2140 in the allelic test (Table 3). However, none of the three SNPs showed significant association in Stage 2, although sample size and power to detect susceptibility SNPs was larger than in Stage 1. We believe that the SNP with replicated significance in both Stage 1 and Stage 2 is regarded as the more likely SNP for T2D association. Unfortunately, none of 112 SNPs reached the statistical confidence level in our sample population.

We next searched for novel SNPs or mutation in the UBR1 gene. Two novel non-synonymous SNPs (M1359I in exon 37 and R1712H in exon 47) were identified by resequencing the UBR1 gene in 48 samples. The SNPs were not common (MAF $=0.02$ and 0.01$)$ and subsequent typing of all of the samples revealed no significance for these two variants in the allelic test ( $p=0.17$ and 0.96 for combined samples). To confirm our data, it will be necessary to test association using a larger number of independent samples.

Fine LD mapping and a haplotype-based association test Haplotype-based association tests assessed as a multilocus test can be more sensitive for the detection of association than assessment by a single-locus association test. To perform this test, we examined LD structure with the pairwise $\left|D^{\prime}\right|$ values of the region, including the UBR1 gene. We searched for additional common variants around putative LD block boundaries with available database. Using the definition of $\left|D^{\prime}\right|>0.95$, we identified a large LD block consisting of 38 SNPs including seven additional SNPs spanning $355 \mathrm{~kb}$ across the UBR1 gene. None of the seven SNPs showed a significant association in Stage 1, Stage 2, or in the combined samples.

For fine mapping of the $355 \mathrm{~kb}$ LD block, we selected seven haplotype-tagging SNPs (htSNPs) from 38 SNPs that captured $>95 \%$ of haplotype frequencies comprising the respective block in all samples, and estimated a haplotype-based association test. A protective haplotype and atrisk haplotype showed a nominal permutation $p$ value ( 0.005 and 0.03 for combined samples) with T2D (Additional file 2). However, after Bonferroni's correction (corrected for 1,317 SNPs multiplied by two + eight haplotypes), $p$ values were not significant for either haplotype.

\section{Discussion}

We applied a region-wide association test as an alternative to GWAS. This approach has been effective in the identification of candidate susceptibility genes in the target regions for T2D $[19,20]$ and rheumatoid arthritis $[33,34]$ in the Japanese population. We hypothesized that there was a high probability of detecting disease susceptibility genes with the use of evenly-spaced common SNP markers in the target region defined by replicated linkage evidence. We could not find any strong variant with singlelocus association test or haplotype analysis in 1,794 Japanese subjects, although one SNP, SNP2140 (rs2412747), in intron 33 of the UBR1 gene showed nominal significance ( $p=0.0043$ for combined samples).

UBR1 encodes an E3 ubiquitin ligase of the N-end rule pathway, a conserved proteolytic pathway of the ubiquitin system whose substrates include proteins with destabilizing N-terminal residues. Recent data suggest that in Johanson-Blizzard syndrome (OMIM 243800), the pancreas exhibits pancreatic exocrine insufficiency and does not express UBR1 [35]. Ubr1 knockout mice exhibit decreased body weight or adipose tissue and an exocrine pancreatic insufficiency [35,36]. In addition, UBR1 mRNA is elevated in the atrophic muscles of diabetic rats [37]. At present, however, the pathophysiological mechanism by which the UBR1 influences T2D is unknown.

Genetic association tests aim to detect true positive associations between a trait and genetic polymorphisms while eliminating false positives. The results of this study have been evaluated within the framework of several criteria. Accordingly, the statistical power (with a MAF of 0.30 ) in Stage 1 or Stage 2 showed $22-60 \%$ or $29-76 \%$, respectively, at detecting the OR of 1.2-1.4 at a significance level of 0.05 (Figure $3 \mathrm{~A}, \mathrm{~B}$ ). Although the power using the whole sample size was estimated as $45-93 \%$, it was not sufficient to detect an association with T2D (Figure 3C). To achieve $60-80 \%$ power (with a MAF of 0.30 and OR of 1.2), 1,400-2,200 each for case and control samples (almost twice as many as those in each stage of this study) is needed. Recent GWAS analyzed more than one thousand cases and controls in Stage 1 and up to more than 10,000 samples in total [2-7], as recommended [38]. Replication studies with thousands of subjects are a priority to determine the consistency of our observations of the UBR1 gene, because it is predicted that true variant(s) have only a modest effect on T2D.

Our samples had the major weakness of an age difference between the case and control subjects (63.0 vs. 41.2). After logistic regression analysis, the association with SNP2140 did not remain statistically significant after adjustment for age and gender. Because aging is an important factor in diabetes development, it is necessary to con- 
Table 3: Top 20 SNPs and the landmark SNP2 I 40 in Stage I allelic and genotypic association tests

\begin{tabular}{|c|c|c|c|c|c|c|c|c|c|c|c|c|c|c|c|c|c|c|c|c|}
\hline & \multirow[b]{2}{*}{$\begin{array}{c}\mathrm{SNP} \\
\text { Marker }\end{array}$} & \multirow[b]{2}{*}{ rs $\#$} & \multirow[b]{2}{*}{$\begin{array}{c}\text { Gene } \\
\text { symbol }\end{array}$} & \multirow[b]{2}{*}{ Position } & \multirow[b]{2}{*}{ Allele $1 / 2$} & \multicolumn{5}{|c|}{ Stage 1} & \multicolumn{5}{|c|}{ Stage 2} & \multicolumn{5}{|c|}{ Stage I + Stage 2} \\
\hline & & & & & & $\begin{array}{l}\text { Allele I } \\
\text { frequency } \\
\text { case }\end{array}$ & $\begin{array}{l}\text { Allele I } \\
\text { frequency } \\
\text { control }\end{array}$ & $\begin{array}{l}p \text { value of } \\
\text { allele } \\
\text { frequency }\end{array}$ & $\begin{array}{l}\text { p value of } \\
\text { genotype } \\
\text { frequency }\end{array}$ & $\begin{array}{l}\text { p value of } \\
\text { Armitage } \\
\text { trend testa) }\end{array}$ & $\begin{array}{l}\text { Allele I } \\
\text { frequency } \\
\text { case }\end{array}$ & $\begin{array}{l}\text { Allele I } \\
\text { frequency } \\
\text { control }\end{array}$ & $\begin{array}{l}p \text { value of } \\
\text { allele } \\
\text { frequency }\end{array}$ & $\begin{array}{l}p \text { value of } \\
\text { genotype } \\
\text { frequency }\end{array}$ & $\begin{array}{l}\text { p value of } \\
\text { Armitage } \\
\text { trend testat) }\end{array}$ & $\begin{array}{l}\text { Allele I } \\
\text { frequency } \\
\text { case }\end{array}$ & $\begin{array}{l}\text { Allele I } \\
\text { frequency } \\
\text { control }\end{array}$ & $\begin{array}{l}p \text { value of } \\
\text { allele } \\
\text { frequency }\end{array}$ & $\begin{array}{l}p \text { value of } \\
\text { genotype } \\
\text { frequency }\end{array}$ & $\begin{array}{c}\text { P value of } \\
\text { Armitage } \\
\text { trend testa) }\end{array}$ \\
\hline 1 & SNP2248 & . & ATP8B4 & 4817563 & $G / T$ & 0.23 & 0.31 & 0.00053 & 0.0024 & 0.00052 & 0.29 & 0.28 & 0.59 & 0.61 & 0.59 & 0.27 & 0.30 & 0.075 & 0.19 & 0.075 \\
\hline 2 & SNP2372 & $\underset{8}{\mathrm{r} s 426146}$ & RAB27A & $\begin{array}{c}2 \\
5334289 \\
4\end{array}$ & $A / G$ & 0.49 & 0.41 & 0.00091 & 0.0034 & 0.00078 & 0.47 & 0.48 & 0.67 & 0.80 & 0.66 & 0.48 & 0.45 & 0.076 & 0.20 & 0.072 \\
\hline 3 & SNP3295 & rs 124431 & intergenic & 4822510 & $C / T$ & 0.34 & 0.43 & 0.00091 & 0.0030 & 0.00099 & 0.38 & 0.40 & 0.49 & 0.66 & 0.49 & 0.37 & 0.41 & 0.0079 & 0.018 & 0.0081 \\
\hline 4 & SNP3347 & rs 138616 & intergenic & 5137677 & $A / G$ & 0.35 & 0.44 & 0.0014 & 0.0013 & 0.0016 & 0.37 & 0.40 & 0.15 & 0.23 & 0.16 & 0.36 & 0.42 & 0.0017 & 0.0080 & 0.0021 \\
\hline 5 & SNPI439 & rs997247 & RAB27A & 5334702 & $\mathrm{~A} / \mathrm{C}$ & 0.30 & 0.23 & 0.0017 & 0.0068 & 0.0016 & 0.27 & 0.29 & 0.28 & 0.34 & 0.27 & 0.28 & 0.26 & 0.25 & 0.37 & 0.25 \\
\hline 6 & SNP3391 & $\mathrm{rs} 241435$ & intergenic & 5274656 & $C / G$ & 0.24 & 0.18 & 0.0019 & 0.0066 & 0.0017 & 0.19 & 0.21 & 0.16 & 0.39 & 0.17 & 0.21 & 0.20 & 0.34 & 0.64 & 0.35 \\
\hline 7 & SNP2373 & $\mathrm{rs}_{4} 30542$ & RAB27A & $\begin{array}{c}5336864 \\
0\end{array}$ & $\mathrm{C} / \mathrm{T}$ & 0.47 & 0.55 & 0.0037 & 0.011 & 0.0032 & 0.48 & 0.48 & 0.97 & 0.86 & 0.96 & 0.48 & 0.51 & 0.061 & 0.11 & 0.058 \\
\hline 8 & SNPI44I & rs241440 & PIGB & 5341900 & $\mathrm{C} / \mathrm{T}$ & 0.47 & 0.55 & 0.0039 & 0.013 & 0.0034 & 0.48 & 0.48 & 0.93 & 0.91 & 0.93 & 0.48 & 0.51 & 0.077 & 0.16 & 0.074 \\
\hline 9 & SNPI 280 & $\mathrm{rs} 227816$ & SLC27A2 & 4828514 & $G / T$ & 0.61 & 0.54 & 0.0050 & 0.014 & 0.0047 & 0.59 & 0.56 & 0.20 & 0.095 & 0.19 & 0.60 & 0.55 & 0.0054 & 0.013 & 0.0047 \\
\hline 10 & SNP2039 & $\mathrm{rs}_{4}{ }_{4}^{\prime} 242$ & FSIPI & $\begin{array}{c}3776542 \\
5\end{array}$ & $C / T$ & 0.65 & 0.59 & $\underline{0.0075}$ & 0.022 & 0.0061 & 0.62 & 0.62 & 0.91 & 0.62 & 0.91 & 0.64 & 0.61 & 0.072 & 0.16 & 0.067 \\
\hline 11 & SNP2098 & $\begin{array}{c}4 \\
\mathrm{rs} 492452 \\
4\end{array}$ & CHACI & $\begin{array}{c}5 \\
3904267 \\
3\end{array}$ & $C / T$ & 0.76 & 0.70 & 0.0060 & 0.022 & 0.0064 & 0.73 & 0.76 & 0.21 & 0.082 & 0.21 & 0.75 & 0.73 & 0.42 & 0.15 & 0.42 \\
\hline 12 & SNPI 440 & rs7718396 & PIGB & $\begin{array}{c}5340998 \\
7\end{array}$ & $C / T$ & 0.47 & 0.54 & 0.0074 & 0.022 & 0.0067 & 0.48 & 0.48 & 0.80 & 0.93 & 0.79 & 0.48 & 0.50 & 0.13 & 0.26 & 0.13 \\
\hline 13 & SNP2249 & rs 16388 & ATP8B4 & 4820389 & $C / G$ & 0.73 & 0.66 & 0.0062 & 0.026 & 0.0069 & 0.67 & 0.68 & 0.72 & 0.89 & 0.72 & 0.70 & 0.67 & 0.15 & 0.33 & 0.15 \\
\hline 14 & SNP3176 & rs996215 & intergenic & 4457711 & $A / G$ & 0.23 & 0.30 & 0.0067 & 0.027 & 0.0073 & 0.28 & 0.27 & 0.51 & 0.74 & 0.50 & 0.26 & 0.28 & 0.22 & 0.46 & 0.22 \\
\hline 15 & SNP2097 & $\mathrm{rs} 492452$ & CHACI & 3904266 & $\mathrm{~A} / \mathrm{T}$ & 0.24 & 0.30 & 0.0072 & 0.025 & 0.0076 & 0.27 & 0.24 & 0.22 & 0.085 & 0.22 & 0.26 & 0.27 & 0.43 & 0.15 & 0.43 \\
\hline 16 & SNP2072 & rs936216 & PAK6 & 3834456 & $\mathrm{~A} / \mathrm{C}$ & 0.75 & 0.81 & 0.0092 & 0.0075 & 0.0084 & 0.75 & 0.78 & 0.093 & 0.14 & 0.10 & 0.75 & 0.79 & 0.0032 & 0.015 & 0.0038 \\
\hline 17 & SNPI 438 & rs 129109 & RAB27A & 5333299 & $C / G$ & 0.33 & 0.27 & 0.0095 & 0.016 & 0.0084 & 0.28 & 0.31 & 0.20 & 0.25 & 0.20 & 0.30 & 0.29 & 0.49 & 0.24 & 0.49 \\
\hline 18 & SNP204I & $\underset{9}{\mathrm{r} s 225482}$ & FSIPI & $\begin{array}{c}8 \\
3777995 \\
7\end{array}$ & $C / T$ & 0.66 & 0.59 & 0.0099 & 0.030 & 0.0085 & 0.63 & 0.62 & 0.84 & 0.67 & 0.84 & 0.64 & 0.61 & 0.071 & 0.17 & 0.068 \\
\hline 19 & SNPI 444 & rs 374320 & CCPGI & 5343625 & $\mathrm{C} / \mathrm{T}$ & 0.47 & 0.53 & 0.010 & 0.037 & 0.010 & 0.47 & 0.47 & 0.98 & 0.83 & 0.98 & 0.47 & 0.49 & 0.11 & 0.22 & 0.10 \\
\hline 20 & SNP3096 & rs 156787 & FLL3953I & $\begin{array}{c}4 \\
3733561 \\
9\end{array}$ & $A / G$ & 0.18 & 0.23 & $\underline{0.0092}$ & 0.038 & 0.011 & 0.18 & 0.21 & 0.065 & 0.065 & 0.062 & 0.18 & 0.22 & 0.0020 & 0.0041 & 0.0022 \\
\hline$*$ & $\underset{0}{\text { SNP214 }}$ & $\underset{47}{\mathrm{rs} 24127}$ & UBRI & 4107409 & $C / T$ & 0.81 & 0.77 & 0.049 & 0.11 & 0.049 & 0.79 & 0.75 & 0.039 & 0.072 & 0.039 & 0.80 & 0.76 & 0.0043 & 0.0081 & 0.0045 \\
\hline
\end{tabular}

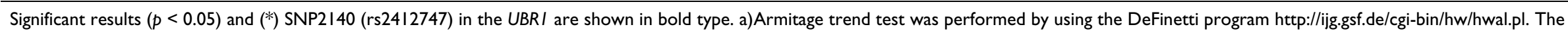

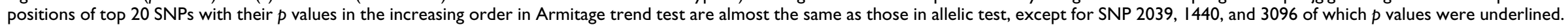


(A)

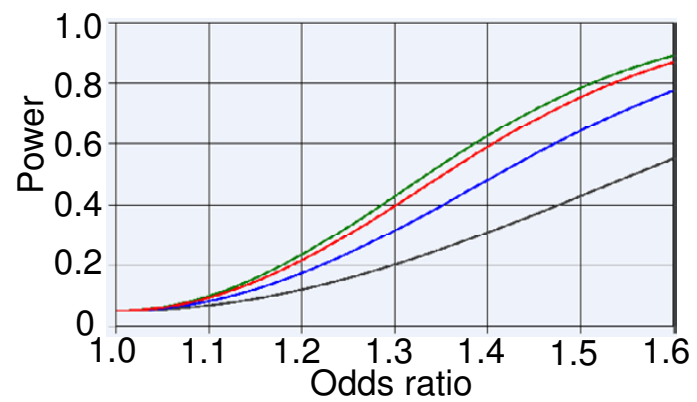

(B)

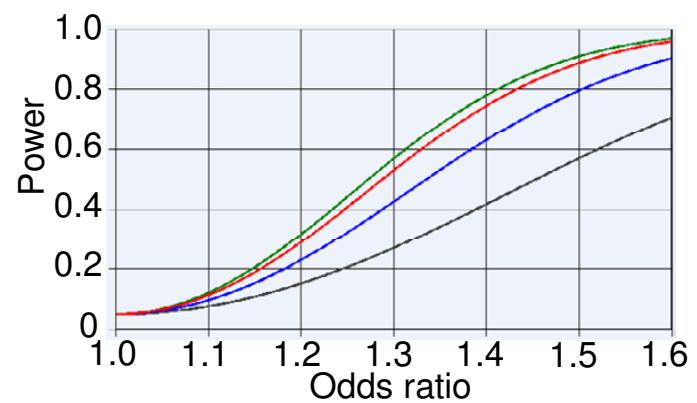

(C)

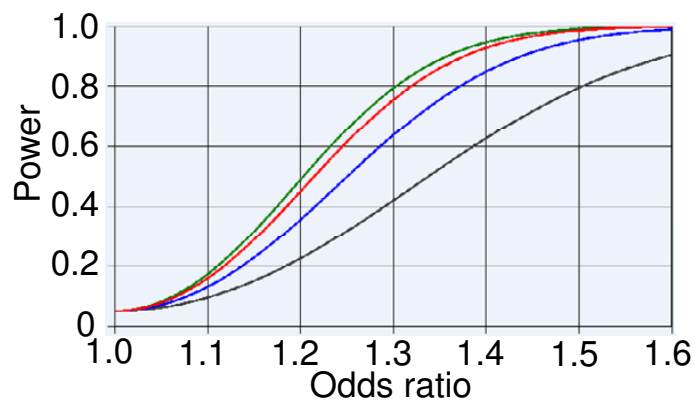

\section{Figure 3}

Power calculation. The power of this case-control association test to detect association against the risk allele frequency with a type I error rate of 0.05 in Stage I samples (A), in Stage 2 samples (B), and combined samples (C). 372 cases and 360 controls subjects were set in Stage I, 532 cases and 530 controls subjects were set in Stage 2, and 904 and 890 controls subjects were set in Stage I + Stage 2 combined samples with variable power and a type I error rate of 0.05. A) - C) graphs were plotted with the PS program.

firm the result of our association test using age-matched control subjects. In selecting the target region for association assessment, the initial linkage studies might overestimate the relevance of chromosome $15 \mathrm{q}$ as a candidate region in the Japanese population. The linkage of chromosome 15q14-22.1 to T2D and its related traits have been replicated in the Japanese at a significant level (LOD $=3.91$ ). However, this LOD score was observed in cases with young onset ( $<45$ years of age) T2D, which is not reflected in our cases (average age $=63.0$ ).

Though SNPs markers were placed, on average, every $9,169 \mathrm{bp}$, which is comparable in density to a genomewide association test using a $500 \mathrm{~kb}$ SNP set ( $\sim 6 \mathrm{~kb})$, it might be necessary to use denser SNPs with shorter intervals. Even though tag SNPs were not available at the onset of this study, tag SNPs with LD information and a highdensity SNP map from the HapMap data would afford useful resources.

Based on these results, we propose that the discovery of a landmark SNP, SNP2140, in the UBR1 gene was statistically marginal and did not reach the confidence level of this study. Other SNPs did not exhibit a strong effect on the risk of T2D within the target region, despite suggestive replicated evidence for linkage in the Japanese population. In addition, a replication study is of prime importance for confirmation of these results.

\section{Conclusion}

The two-stage association test on chromosome 15q1422.1 failed to detect an association between T2D and SNPs in the target region. These observations could uncover new insights on the susceptibility variant(s) on chromosome $15 \mathrm{q}$ that might be used as a guide for further association tests, including replication and/or meta-analysis. Replication studies in other independent populations are a priority if the consistency of our observations is to be determined.

\section{Competing interests}

The author(s) declare that they have no competing interests.

\section{Authors' contributions}

YY carried out genotyping, sequencing, the association test, and LD analysis, and contributed to experimental design and manuscript writing. MM contributed to manuscript design and manuscript writing. DO, KN, and YF performed genotyping, performed the association test and LD analysis. TT, PK, and KK contributed to the development of statistical genetics concepts and maintained storage of the DNA samples. NN, TY, EI, HS, and NY supplied T2D DNA samples. HI and MI contributed to project design. All authors read and approved the final manuscript. 


\section{Additional material}

\section{Additional file 1}

Association tests in Stage 1, Stage 2, and Stage $1+$ Stage 2 . A complete list of the 1,317 SNP markers used in this study, and the results of association tests in Stage 1, Stage 2, and Stage $1+$ Stage 2.

Click here for file

[http://www.biomedcentral.com/content/supplementary/14712350-9-22-S1.xls]

\section{Additional file 2}

Haplotype-based association test with seven htSNPs by $\left|D^{\prime}\right|$. Inferred haplotype frequency and a haplotype-based association test on the landmark LD block across $355 \mathrm{~kb}$.

Click here for file

[http://www.biomedcentral.com/content/supplementary/14712350-9-22-S2.doc]

\section{Acknowledgements}

This study was supported by a grant from the Cooperative Link of Unique Science and Technology for Economy Revitalization (CLUSTER) and Immediate Type Regional Technology Consortium Enterprise from Ministry of Economy, Trade \& Industry.

\section{References}

I. Saltiel AR: New perspectives into the molecular pathogenesis and treatment of type 2 diabetes. Cell 200I, 104(4):517-529.

2. Sladek R, Rocheleau G, Rung J, Dina C, Shen L, Serre D, Boutin P, Vincent D, Belisle A, Hadjadj S, Balkau B, Heude B, Charpentier G, Hudson TJ, Montpetit A, Pshezhetsky AV, Prentki M, Posner BI, Balding DJ, Meyre D, Polychronakos C, Froguel P: A genome-wide association study identifies novel risk loci for type 2 diabetes. Nature 2007, 445(7 | 30):88I-885.

3. Steinthorsdottir V, Thorleifsson G, Reynisdottir I, Benediktsson R, Jonsdottir T, Walters GB, Styrkarsdottir U, Gretarsdottir S, Emilsson V, Ghosh S, Baker A, Snorradottir S, Bjarnason H, Ng MC, Hansen T, Bagger Y, Wilensky RL, Reilly MP, Adeyemo A, Chen Y, Zhou J, Gudnason V, Chen G, Huang H, Lashley K, Doumatey A, So WY, Ma RC, Andersen G, Borch-Johnsen K, et al.: A variant in CDKALI influences insulin response and risk of type 2 diabetes. Nat Genet 2007, 39(6):770-775.

4. Saxena R, Voight BF, Lyssenko V, Burtt NP, de Bakker PI, Chen H, Roix JJ, Kathiresan S, Hirschhorn JN, Daly MJ, Hughes TE, Groop L, Altshuler D, Almgren P, Florez JC, Meyer J, Ardlie K, Bengtsson BK, Isomaa B, Lettre G, Lindblad U, Lyon HN, Melander O, Newton-Cheh $C$, Nilsson $\mathrm{P}$, Orho-Melander M, Råstam L, Speliotes EK, Taskinen $M R$, Tuomi T, et al:: Genome-wide association analysis identifies loci for type 2 diabetes and triglyceride levels. Science 2007, 3 |6(5829): | $33|-| 336$.

5. Zeggini E, Weedon MN, Lindgren CM, Frayling TM, Elliott KS, Lango $H$, Timpson NJ, Perry JR, Rayner NW, Freathy RM, Barrett JC, Shields B, Morris AP, Ellard S, Groves C], Harries LW, Marchini JL, Owen KR, Knight B, Cardon LR, Walker M, Hitman GA, Morris AD, Doney AS, Burton PR, Clayton DG, Craddock N, Deloukas P, Duncanson A, Kwiatkowski DP, et al.: Replication of genome-wide association signals in UK samples reveals risk loci for type 2 diabetes. Science 2007, 3 | 6(5829): | 336-| $34 \mid$.

6. Scott LJ, Mohlke KL, Bonnycastle LL, Willer CJ, Li Y, Duren WL, Erdos MR, Stringham HM, Chines PS, Jackson AU, Prokunina-Olsson L, Ding C], Swift AJ, Narisu N, Hu T, Pruim R, Xiao R, Li XY, Conneely KN, Riebow NL, Sprau AG, Tong M, White PP, Hetrick KN, Barnhart MW, Bark CW, Goldstein JL, Watkins L, Xiang F, Saramies J, et al.: A genome-wide association study of type 2 diabetes in Finns detects multiple susceptibility variants. Science 2007, 3 | 6(5829): | 34|-| 345 .
7. Wellcome Trust Case Control Consortium: Genome-wide association study of 14,000 cases of seven common diseases and 3,000 shared controls. Nature 2007, 447(7 I 45):66I-678.

8. Frayling TM: Genome-wide association studies provide new insights into type 2 diabetes aetiology. Nat Rev Genet 2007, 8(9):657-662.

9. Ehm MG, Karnoub MC, Sakul H, Gottschalk K, Holt DC, Weber JL, Vaske D, Briley D, Briley L, Kopf J, McMillen P, Nguyen Q, Reisman M, Lai EH, Joslyn G, Shepherd NS, Bell C, Wagner MJ, Burns DK: Genomewide search for type 2 diabetes susceptibility genes in four American populations. Am J Hum Genet 2000, 66(6): $|87|-|88|$.

10. Elbers CC, Onland-Moret NC, Franke L, Niehoff AG, van der Schouw YT, Wijmenga C: A strategy to search for common obesity and type 2 diabetes genes. Trends Endocrinol Metab 2007, I 8(I): 19-26.

II. Mori Y, Otabe S, Dina C, Yasuda K, Populaire C, Lecoeur C, Vatin V, Durand E, Hara K, Okada T, Tobe K, Boutin P, Kadowaki T, Froguel $P$ : Genome-wide search for type 2 diabetes in Japanese affected sib-pairs confirms susceptibility genes on $3 q$, I5q, and $20 \mathrm{q}$ and identifies two new candidate Loci on $7 \mathrm{p}$ and I I $\mathrm{p}$. Diabetes 2002, 5 I (4): I 247- I 255.

12. Iwasaki N, Cox NJ, Wang YQ, Schwarz PE, Bell GI, Honda M, Imura M, Ogata M, Saito M, Kamatani N, Iwamoto Y: Mapping genes influencing type 2 diabetes risk and BMI in Japanese subjects. Diabetes 2003, 52(1):209-213.

13. Nawata H, Shirasawa S, Nakashima N, Araki E, Hashiguchi J, Miyake $\mathrm{S}$, Yamauchi T, Hamaguchi K, Yoshimatsu H, Takeda H, Fukushima $\mathrm{H}$, Sasahara T, Yamaguchi K, Sonoda N, Sonoda T, Matsumoto M, Tanaka Y, Sugimoto H, Tsubouchi H, Inoguchi T, Yanase T, Wake N, Narazaki K, Eto T, Umeda F, Nakazaki M, Ono J, Asano T, Ito Y, Akazawa S, et al.: Genome-wide linkage analysis of type 2 diabetes mellitus reconfirms the susceptibility locus on IIp I 3-p I 2 in Japanese. J Hum Genet 2004, 49(II):629-634.

14. Hanis CL, Boerwinkle E, Chakraborty R, Ellsworth DL, Concannon P, Stirling B, Morrison VA, Wapelhorst B, Spielman RS, Gogolin-Ewens KJ, Shepard JM, Williams SR, Risch N, Hinds D, Iwasaki N, Ogata M, Omori Y, Petzold C, Rietzch H, Schröder HE, Schulze J, Cox NJ, Menzel S, Boriraj VV, Chen X, Lim LR, Lindner T, Mereu LE, Wang YQ, Xiang $\mathrm{K}$, et al.: A genome-wide search for human non-insulindependent (type 2) diabetes genes reveals a major susceptibility locus on chromosome 2. Nat Genet 1996, I3(2):161-166.

15. Pratley RE, Thompson DB, Prochazka M, Baier L, Mott D, Ravussin E, Sakul H, Ehm MG, Burns DK, Foroud T, Garvey WT, Hanson RL, Knowler WC, Bennett PH, Bogardus C: An autosomal genomic scan for loci linked to prediabetic phenotypes in Pima Indians. J Clin Invest 1998, IOI(8): I757-1764.

16. Cox NJ, Frigge M, Nicolae DL, Concannon P, Hanis CL, Bell GI, Kong A: Loci on chromosomes 2 (NIDDMI) and 15 interact to increase susceptibility to diabetes in Mexican Americans. Nat Genet 1999, 2 I(2):2। 3-215.

17. Pharma SNP consortium [http://ssl.g-02.jp/psc/frame-e.html]

18. De La Vega FM, Isaac H, Collins A, Scafe CR, Halldórsson BV, Su X, Lippert RA, Wang Y, Laig-Webster M, Koehler RT, Ziegle JS, Wogan LT, Stevens JF, Leinen KM, Olson SJ, Guegler KJ, You X, Xu LH, Hemken HG, Kalush F, Itakura M, Zheng Y, de Thé G, O'Brien SJ, Clark AG, Istrail S, Hunkapiller MW, Spier EG, Gilbert DA: The linkage disequilibrium maps of three human chromosomes across four populations reflect their demographic history and a common underlying recombination pattern. Genome Res 2005, 15(4):454-462.

19. Kato H, Nomura K, Osabe D, Shinohara S, Mizumori O, Katashima R, Iwasaki S, Nishimura K, Yoshino M, Kobori M, Ichiishi E, Nakamura N, Yoshikawa T, Tanahashi T, Keshavarz P, Kunika K, Moritani M, Kudo E, Tsugawa K, Takata Y, Hamada D, Yasui N, Miyamoto T, Shiota $\mathrm{H}$, Inoue $\mathrm{H}$, Itakura M: Association of single-nucleotide polymorphisms in the suppressor of cytokine signaling 2 (SOCS2) gene with type 2 diabetes in the Japanese. Genomics 2006, 87(4):446-458

20. Moritani M, Nomura K, Tanahashi T, Osabe D, Fujita Y, Shinohara S, Yamaguchi Y, Keshavarz P, Kudo E, Nakamura N, Yoshikawa T, Ichiishi E, Takata Y, Yasui N, Shiota H, Kunika K, Inoue H, Itakura M: Genetic association of single nucleotide polymorphisms in endonuclease G-like I gene with type 2 diabetes in a Japanese population. Diabetologia 2007, 50(6): | $218-1227$.

21. Tanahashi T, Osabe D, Nomura K, Shinohara S, Kato H, Ichiishi E, Nakamura N, Yoshikawa T, Takata Y, Miyamoto T, Shiota H, Kesha- 
varz $\mathrm{P}$, Yamaguchi Y, Kunika K, Moritani M, Inoue H, Itakura M: Association study on chromosome 20qII.2I-13.13 locus and its contribution to type 2 diabetes susceptibility in Japanese. Hum Genet 2006, I 20(4):527-542.

22. Iwane M, Palensky J, Plante K: A user's review of commercial sample size software for design of biomedical studies using survival data. Control Clin Trials 1997, 18(1):65-83.

23. PS program [http://biostat.mc.vanderbilt.edu/twiki/bin/view/Main/ PowerSampleSize]

24. McIntyre LM, Martin ER, Simonsen KL, Kaplan NL: Circumventing multiple testing: a multilocus Monte Carlo approach to testing for association. Genet Epidemiol 2000, 19(1):18-29.

25. Storey JD: A direct approach to false discovery rates. J Roy Stat Soc Ser B 2002, 64(3):479-498.

26. FDR program [http://genomics.princeton.edu/storeylab/qvalue/]

27. SNPAlyze program [http://www.dynacom.co.jp/e/products/pack age/snpalyze/]

28. International HapMap Consortium: A haplotype map of the human genome. Nature 2005, 437(7063): 1299-1320.

29. The International HapMap Project [http://www.hapmap.org/ index.html]

30. Tagger program [http://www.broad.mit.edu/mpg/tagger/]

31. NCBI Build 36.I human genome [http://www.ncbi.nlm.nih.gov/ Genomes/]

32. dbSNP [http://www.ncbi.nlm.nih.gov/SNP/]

33. Hamada D, Takata $Y$, Osabe D, Nomura K, Shinohara S, Egawa $H$, Nakano S, Shinomiya F, Scafe CR, Reeve VM, Miyamoto T, Moritani M, Kunika K, Inoue H, Yasui N, Itakura M: Association between single-nucleotide polymorphisms in the SEC8LI gene, which encodes a subunit of the exocyst complex, and rheumatoid arthritis in a Japanese population. Arthritis Rheum 2005, 52(5): $137 \mid-1380$

34. Takata $Y$, Hamada D, Miyatake K, Nakano S, Shinomiya F, Scafe CR, Reeve VM, Osabe D, Moritani M, Kunika K, Kamatani N, Inoue H, Yasui N, Itakura M: Genetic association between the PRKCH gene encoding protein kinase Ceta isozyme and rheumatoid arthritis in the Japanese population. Arthritis Rheum 2007, 56(I):30-42

35. Zenker M, Mayerle J, Lerch MM, Tagariello A, Zerres K, Durie PR, Beier M, Hülskamp G, Guzman C, Rehder H, Beemer FA, Hamel B, Vanlieferinghen P, Gershoni-Baruch R, Vieira MW, Dumic M, Auslender R, Gil-da-Silva-Lopes VL, Steinlicht S, Rauh M, Shalev SA, Thiel C Ekici AB, Winterpacht A, Kwon YT, Varshavsky A, Reis A: Deficiency of UBRI, a ubiquitin ligase of the $\mathrm{N}$-end rule pathway, causes pancreatic dysfunction, malformations and mental retardation (Johanson-Blizzard syndrome). Nat Genet 2005, 37( I 2): I345-1350.

36. Kwon YT, Xia Z, Davydov IV, Lecker SH, Varshavsky A: Construction and analysis of mouse strains lacking the ubiquitin ligase UBRI (E3alpha) of the $\mathbf{N}$-end rule pathway. Mol Cell Biol 200I 2I(23):8007-802I.

37. Lecker SH, Solomon V, Price SR, Kwon YT, Mitch WE, Goldberg AL: Ubiquitin conjugation by the $\mathrm{N}$-end rule pathway and mRNAs for its components increase in muscles of diabetic rats. J Clin Invest 1999, 104(10): | 4 I I-1420.

38. Cordell HJ, Clayton DG: Genetic association studies. Lancet 2005, 366(949I):||2|-||3|.

\section{Pre-publication history}

The pre-publication history for this paper can be accessed here:

http://www.biomedcentral.com/1471-2350/9/22/prepub

\section{Publish with Biomed Central and every} scientist can read your work free of charge

"BioMed Central will be the most significant development for disseminating the results of biomedical research in our lifetime. "

Sir Paul Nurse, Cancer Research UK

Your research papers will be:

- available free of charge to the entire biomedical community

- peer reviewed and published immediately upon acceptance

- cited in PubMed and archived on PubMed Central

- yours - you keep the copyright
BioMedcentral 